\title{
Presence of Monoaminergic Neurons in the Spinal Cord and Intestine of the Lamprey, Lampetra japonica*
}

\author{
Shinji Honma（本 間 信 治）
}

(Received September 9, 1970)

It is said that the lamprey has no commissural sympathetic chain (NICOL, 1952; JoHNELs, 1956), although visceral efferents from the vagus are described (JoHNELS, 1956). It is not clear whether the visceral efferents coming from the spinal cord emerge from the dorsal or ventral roots or both. Ayers $(1921,1930)$ found the visceral efferents emerging from the ventral roots in Amphioxus and Myxinoid and suggested the presence of similar visceral efferents in the lamprey. GoodRICH (1930) stated that the visceral efferents arise from the dorsal root nerves in the lamprey. On the other hand, JoHNELs (1956) described the presence of visceral efferents emerging from both the dorsal and ventral roots. It is not certain whether the monoaminergic nerve fibers are present in these spinal efferents. If they exist, then it seems probable that the monoaminergic neurons might be present in the spinal cord of the lamprey. These observations were made to prove the presence of monoaminergic neurons in the lamprey spinal cord.

In mammalian intestinal wall, no adrenergic neuronal somata seem to be present, although the adrenergic fibers are found around the neurons of the plexus of Auerbach and in the muscle layer (NoRBERG, 1964; Hollands and VANov, 1965). The presence of neuronal somata and fibers in the intestinal wall and that of the ganglion dorsal to the caudal end part of the ureter have been described in the lamprey (JohneLs, 1956). It is not clear, however, whether the monoaminergic neural elements exist in these tissues. In the present study, these tissues were examined by using the Falck-Hillarp method for the demonstration of cells containing biogenic monoamines (FALCK and OwMAN, 1965).

\section{Materials and Methods}

Adult river lampreys collected in winter (Lampetra japonica) were chiefly used as in the previous study on the lamprey brain (HonmA, 1969). Several adults and ammocoetes of brook lampreys (Lampetra planeri) were also used. Method after FALCK and HILLARP (FALCK and OWMAN, 1965) was employed as in the previous studies (Honma, 1969, $1970 \mathrm{a}, \mathrm{b}$ ). The tissues examined were the spinal cord, the intestine and the ganglion dorsal to the ureter of the caudal end part. As the specificity test for monoamine fluorescence, comparison between the formaldehyde-treated and nontreated specimens, reserpine administration (reserpine, Ciba; about 3 to $15 \mathrm{mg} / \mathrm{kg}$ ) and sodium borohydride reduction of fluorescence were tried (Corrodi et al., 1964).

*A part of this paper was presented in the 47 th general meeting of the Physiological Society of Japan (HONMA, 1970). 


\section{Observations}

\section{Spinal cord}

Fluorescent neurons were found in the spinal cord of the river lamprey. They were encountered closely around the central canal, covering almost the whole length of the spinal cord (Fig. 1). Their round to oval perikarya were about $10 \mu$ in diameter.

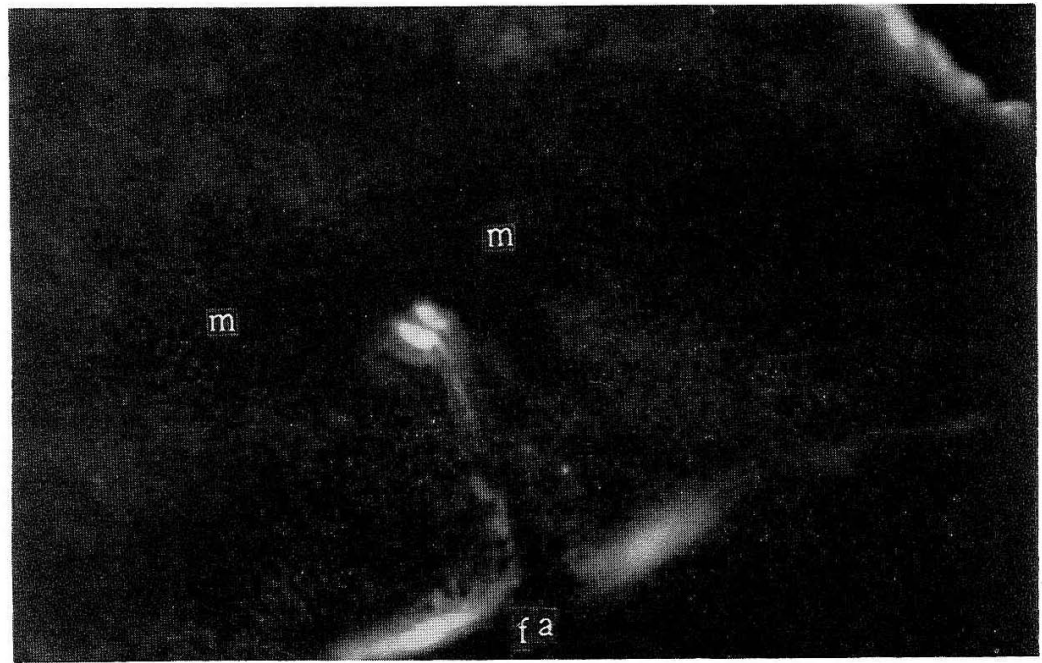

Fig. 1. A cross section of river lamprey spinal cord. A pair of fluorescent neurons among the Müller fibers $(m)$, and fluorescent areas $(f a)$ near the ventral surface of the cord are seen. An axon seems to run toward the ventral side of the flattened spinal cord. $\times 100$

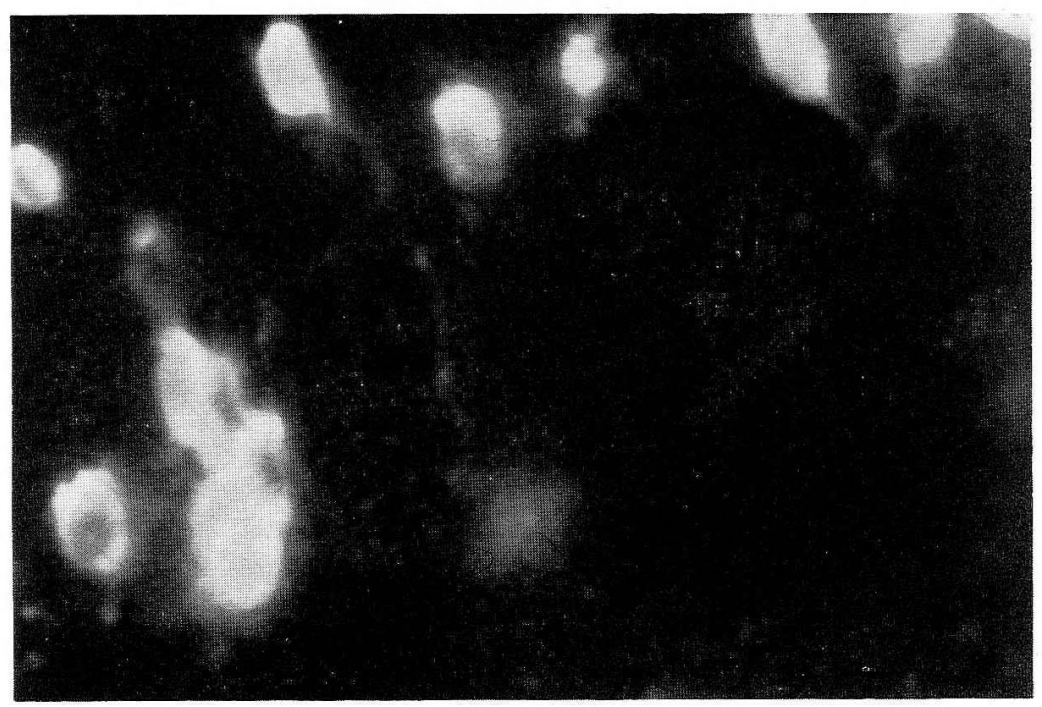

Fig. 2. A sagittal section of lamprey spinal cord. Axons of the fluorescent neurons seem to travel to the ventral side of the cord. $\times 400$ 
The axons ran ventrally in almost all cases (Fig. 2). It was impossible to follow the processes to the dorsal or lateral direction for a long distance. Near the ventral surface of the spinal cord, a pair of fluorescent areas were seen on each side of the central canal. These areas showed accumulations of fine fluorescent spots, which seemed to be the cut surfaces or endings of the axons of the fluorescent neurons in the cord. In horizontal, cross (Fig. 3) and sagittal sections (Fig. 4), these areas were

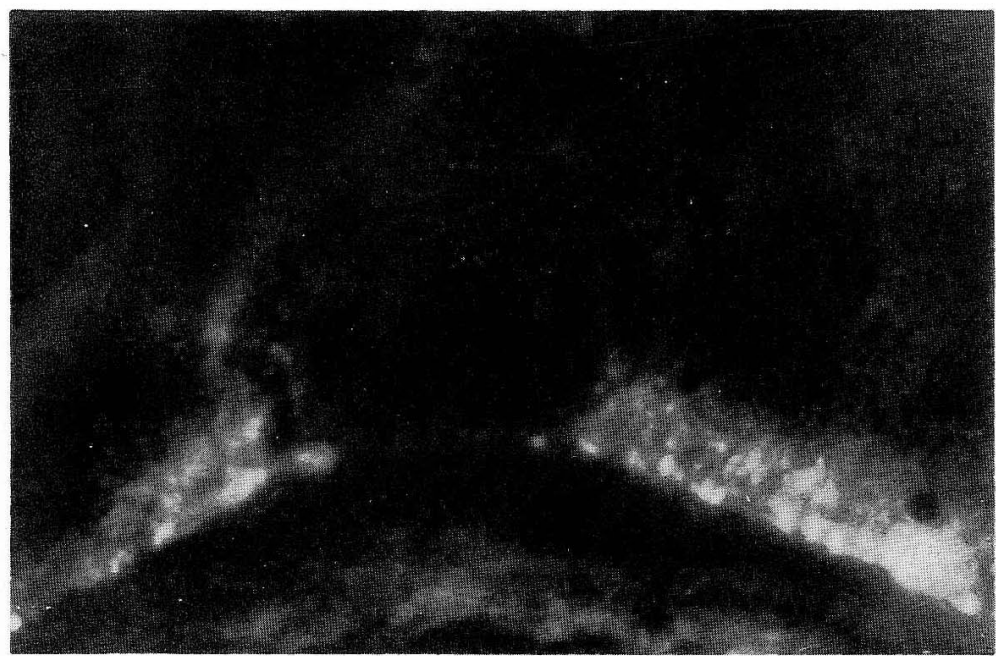

Fig. 3. A cross section showing a pair of fluorescent areas in the vicinity of the ventral surface of the spinal cord. The fluorescent areas seem to be composed of fine fluorescent spots as seen in the horizontal sections of the cord. $\times 400$

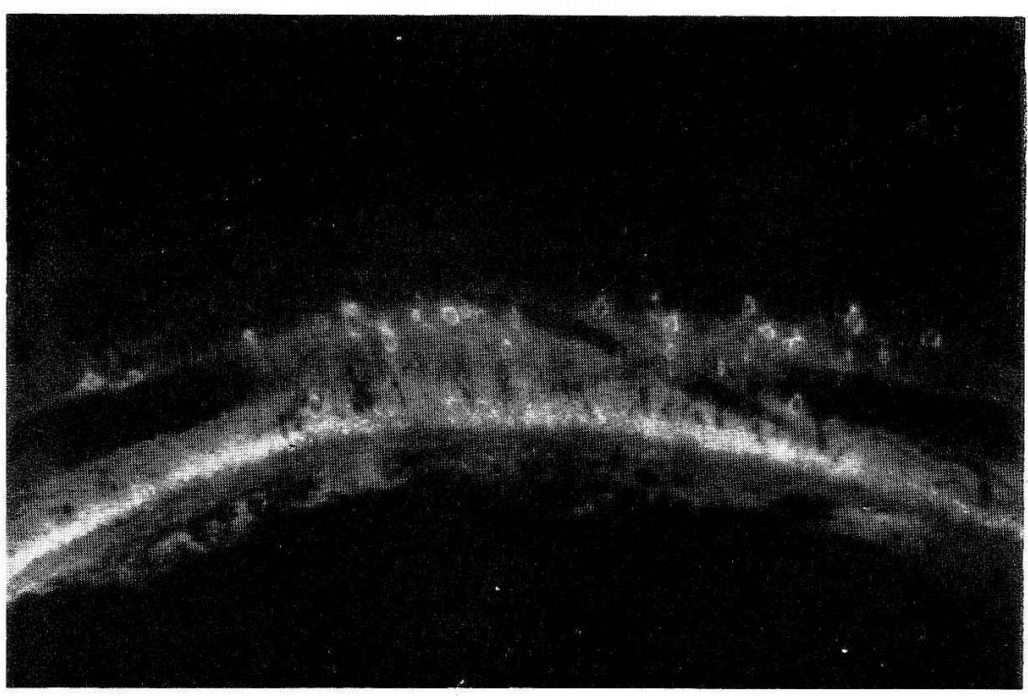

Fig. 4. A sagittal section of the spinal cord showing the almost even distribution of the fluorescent neurons along the longitudinal axis of the spinal cord. The fluorescent area also seems to consist of fine fluorescent spots. $\times 100$ 
seen as the accumulations of fluorescent spots. It was supposed that if some of the fluorescent axons in the cord ran longitudinally in the areas, their length seemed to be very short. Most of them seemed to end near the ventral surface of the cord.

No fluorescence was recognized in or around the dorsal cells; giant interneuron; and other small neurons which were present laterally to these large neurons. The Müller and Mauthner fibers also did not fluoresce (Fig. 5). The ampullary enlargement of the caudal end of the spinal cord was omitted from the present observation

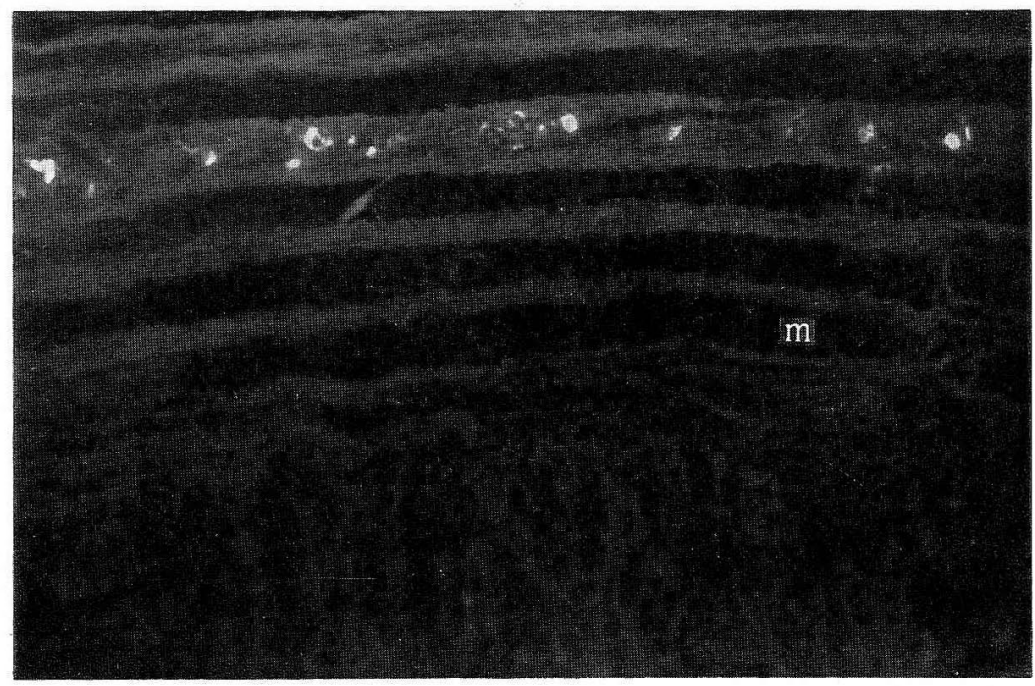

Fig. 5. A horizontal section of the spinal cord to show no fluorescence in the Müller fibers $(m)$ and in the other neurons which are present laterally to the Müller fibers. $\times 100$

The fluorescent neurons and fluorescent areas were also found in the adult brook lamprey and its ammocoetes, but it was difficult to find those relations between them as seen in the adult river lampreys.

\section{Blood vessels to the caudal end part of the intestine}

Fluorescent fibers with varicosities were found in the wall of the blood vessels to the caudal end part of the intestine. They seemed to enter the intestine, but it was impossible to follow them to termination on other neural elements or muscles of the intestinal wall (Fig. 6,7). These fibers were confirmed to be present in the vascular wall by the Bodian method.

\section{Ganglion present dorsally to ureter of the cloacal region}

Dense accumulations of fluorescent fibers and cell bodies were encountered in the vicinity of the ureters of the cloacal region (Fig. 8, 9). Some fluorescent fibers seemed to pass the ganglion through and ran directly to the viscera (Fig. 8) It was possible to see the fluorescent fibers emerging from the ganglion cells (Fig. 9). The round to oval perikarya measured about $25 \mu$ in diameter. These ganglion cells which seemed usually unipolar could be demonstrated in Bodian stained preparations. No fluorescent network around the ganglion cells were seen in this study. 


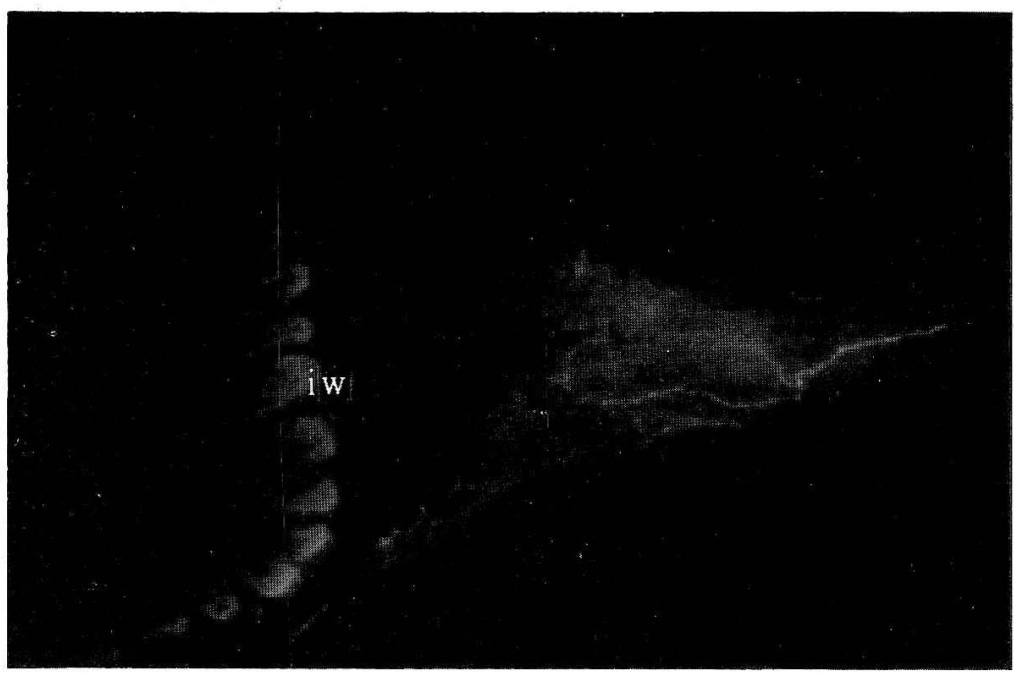

Fig. 6. Varicose fluorescent fibers seen in the wall of the blood vessels to the intestine of the caudal part. The intestinal wall $(i w)$ is seen at the left side of the figure $\times 40$

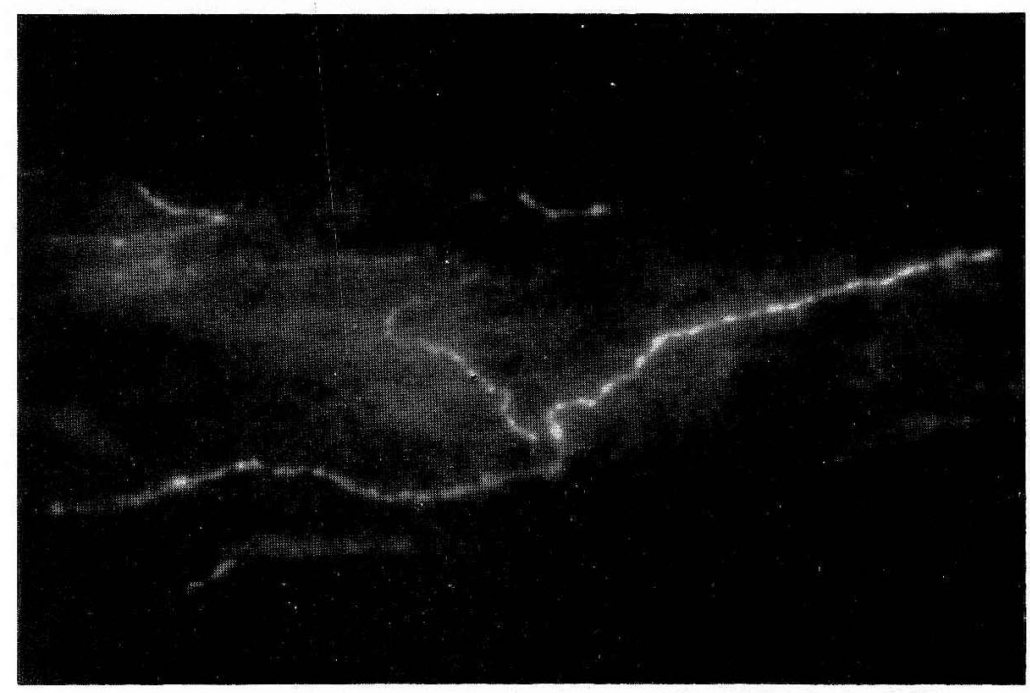

Fig. 7. Closer view of Figure $6 . \times 100$

\section{Intestinal wall}

The portions of the intestine from the liver region to the cloacal end were examined. Many small type neurons about $10 \mu$ in diameter, were constantly found in the muscle layer of almost the intestine (Fig. $10 \mathrm{~A}$ ). Large type neurons, about $25 \mu$ in diameter, were very few in number and it was difficult to see the axons just leaving from the somata (Fig. 10B). Small type neurons were mostly unipolar and sometimes bipolar; pseudounipolar type neurons were rare. Large type neurons were bipolar or unipolar. Fluorescent fibers were scarce or sometimes densely 
scattered in the intestinal wall (Fig. 11). By the Bodian method, large type neurons could easily be silver-impregnated, but neurons corresponding to the small type could not be demonstrated.

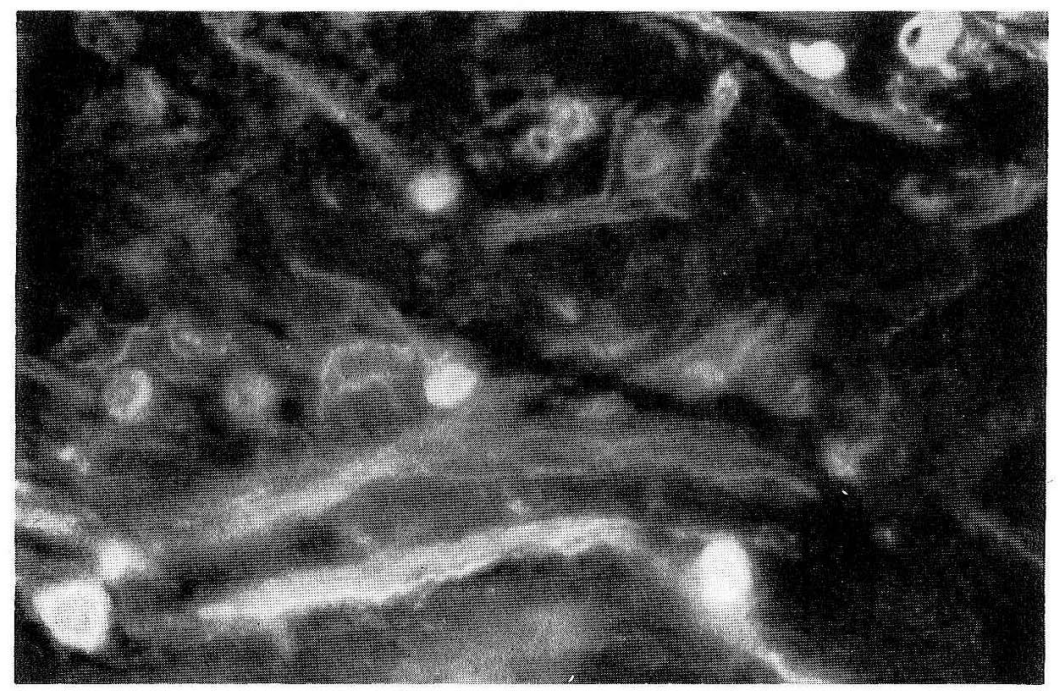

Fig. 8. A cloacal sympathetic ganglion. Many fluorescent neurons and fibers are seen. The fluorescent fibers seem to enter the ganglion, or to leave the ganglion without relation to the fluorescent neurons. $\times 100$

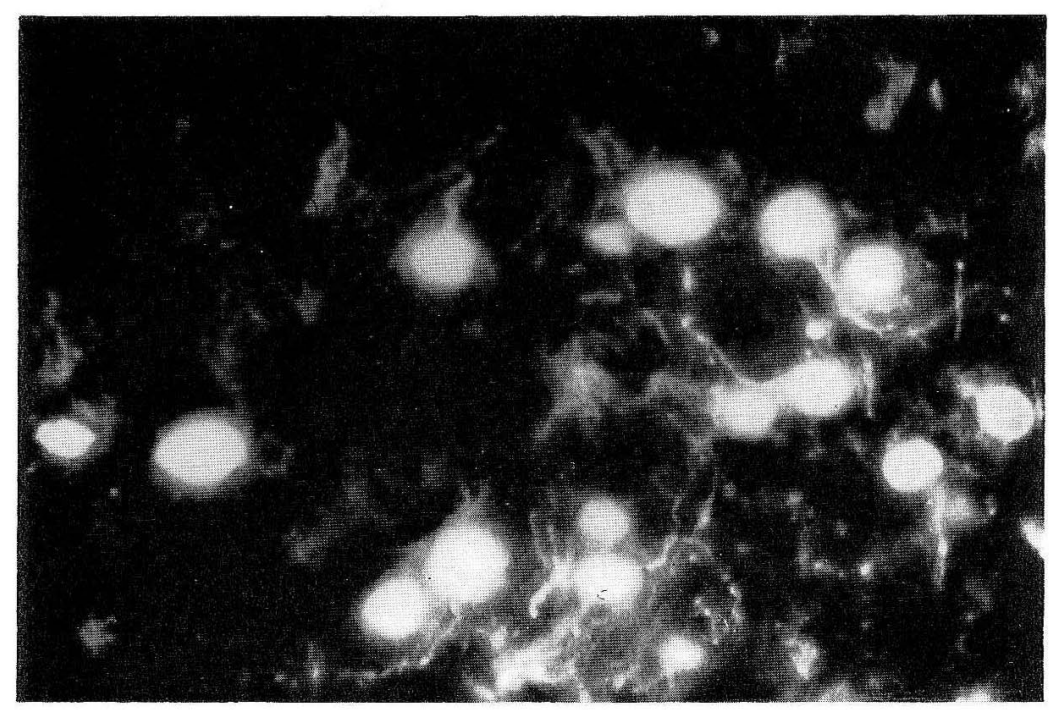

Fig. 9. Densely accumulated fluorescent neurons in the cloacal sympathetic ganglion. Fluorescent fibers seem to originate from the fluorescent ganglion cells. 


\section{Fluorescence specificity of monoamines}

Ten hrs after an intraperitoneal injection of reserpine in a dose as high as $15 \mathrm{mg} / \mathrm{kg}$ body weight, a remarkable reduction in fluorescence was seen as compared with non-reserpinized control specimens. Fluorescence of the neural elements found in this examination was seen to disappear by sodium borohydride treatment under direct fluorescence-microscopic observation. In the case of the fluorescent

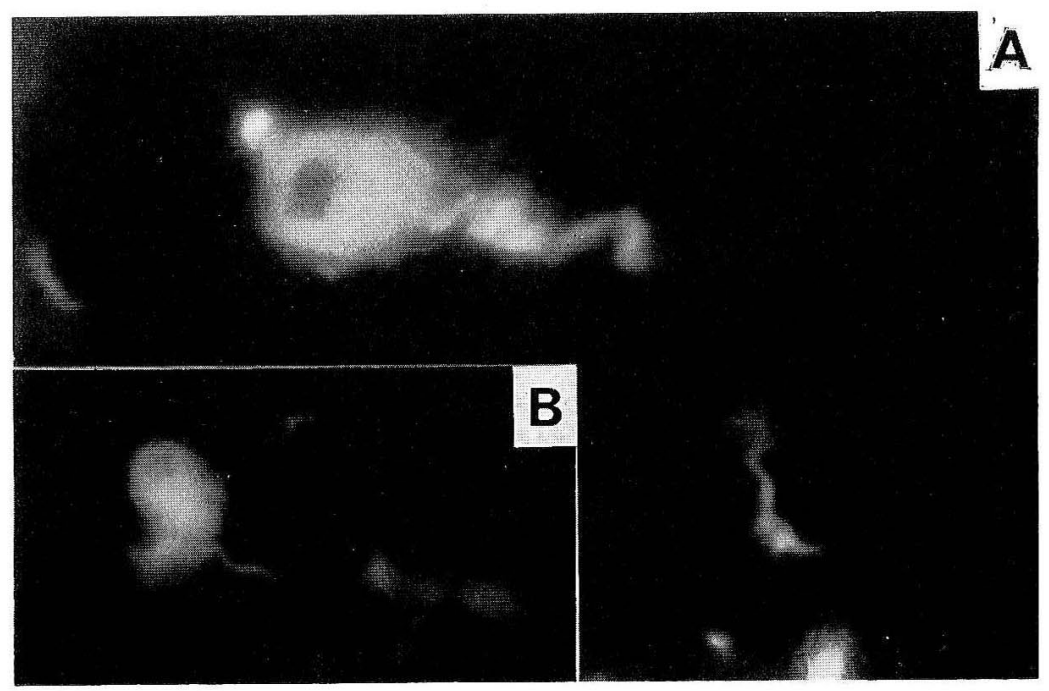

Fig. 10. Typical large and small types of intestinal neurons. A: A large type fluorescent neuron of the intestine. From its soma an axon is just leaving.

B: A small type fluorescent neuron of the intestine. $\times 400$

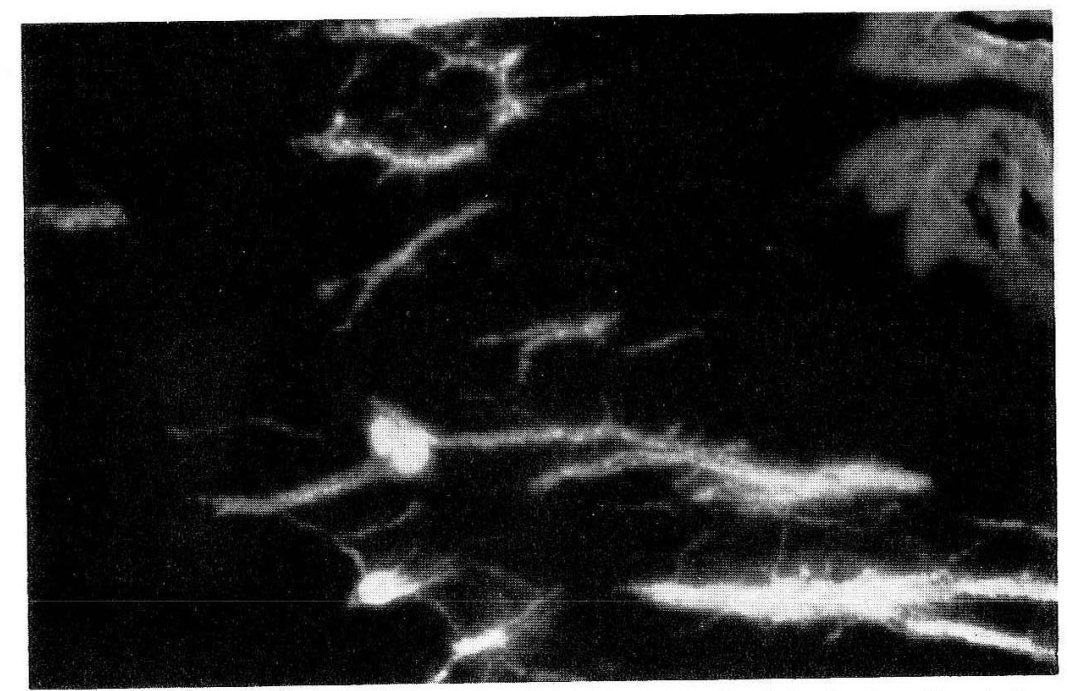

Fig. 11. Densely accumulated fluorescent fibers in the intestinal wall. A few small type intestinal neurons are seen. A parahorizontal section. $\times 100$ 
spinal neurons, reappearance of fluorescence was confirmed by re-exposure of the specimens to formaldehyde gas, after complete reduction of fluorescence by sodium borohydride treatment (CoRRoDi et al , 1964). In all the control specimens not treated with formaldehyde gas, neural elements did not fluoresce.

\section{Discussion}

By the simple monoamine fluorescence specificity tests above described, all the fluorescent neural elements shown in the present study were supposed to be monoaminergic, although further chemical analysis and microspectrophotofluorometry must be done to confirm it. These fluorescent neural elements seem to exert sympathetic influences on the viscera of the lamprey, referring to the reports that the intestine of the myxine responds to catecholamines as in higher vertebrates (FÄNGE, 1948; EUler and Östlund, 1957; FäNGE and JohNELS, 1959).

Do the monoaminergic neurons found in the spinal cord send out axons into the spinal nerves? A few dorsally directed processes were encountered but could not be followed into the spinal nerves, in either dorsal or ventral roots. On the other hand, the fluorescent fiber-like structures were found both in the dorsal and ventral roots. In addition, fluorescent fibers were seen to run around the notochord and seemed to travel to the viscera in the case of the brook lamprey, though it was not confirmed in the present preparation whether these fibers emerged from the dorsal or ventral or both roots. The root through which the monoaminergic fibers emerge is uncertain, and it is unknown whether the fluorescent neurons in the spinal cord could be the sources of the visceral monoaminergic efferents deriving from the spinal nerves. These problems need further precise examination and are now under investigation.

What is the destiny, on the other hand, of the axons toward the ventral side? There are no intramedullary blood vessels, while the network of blood vessels exist in the pial membrane (KAPPERS et al., 1936; Schultz et al., 1956). If the axons of the fluorescent neurons in the cord are proved to be related to the blood vessels in the pial membrane on the ventral surface of the cord, it is conceivable that their monoamines would be released into the capillaries there and circulate through the whole body to exert some physiological functions as in the case of adrenal medullary tissue of higher vertebrates. Electron microscopical investigations must be done to see the relations between the fluorescent axons and capillaries. In any case, the function of the spinal fluorescent neurons is quite uncertain.

In the mammalian spinal cord, fluorescent descending fibers from the brain stem form a network on the lateral horn cells, i.e., sympathetic preganglionic neurons, with a few fibers directly going into the ventral roots without interneurons (CARLSON et al., 1964; DAhLström et al., 1965 a, b, c; Konishi, 1968). In the lamprey, neurons which correspond to the sympathetic preganglionic neurons of higher vertebrates seem not to be identified, except the presumable postganglionic neurons in different viscera such as the testis, kidney, ureter, intestine and cloacal part (JoHNELs, 1956). Fluorescent descending fibers are unlikely to be present in the lamprey either, referring to the findings that, in the cross, horizontal and sagittal sections of the cord, the fluorescent structures were represented by spots instead of lines. If such descending fibers are present, it is conceivable that the neurons found in the inferior 
part of the optic lobe might be their source, though the axons of the neurons were not traced in the previous work on the lamprey brain (HonMA, 1969).

Ontogenetically, it has been said that in many higher vertebrates the sympathetic postganglionic neurons originate from neuroblasts which developed from the neural crest (YNTEMA und HAMMOND, 1947). On the other hand, the primordial intestinal neurons have been said to migrate into the gut along the vagal nerve in fishes and amphibians (KUNTZ, $1911 \mathrm{a}$, b) or along both sympathetic and vagal nerves in the dog fish (MÜLLER, 1920). The enteric plexus is said to derive from the spinal sympathoblasts in amphibia (CAMPENHout, 1930). It seems probable that in higher vertebrates with commissural sympathetic ganglia, no fluorescent neurons may be present in the spinal cord even in selachians with incomplete commissural sympathetic connectives (YounG, 1933). It is conceivable also that in phylogeny the neurons similar to these fluorescent ones in the spinal cord of the lamprey may migrate out through the spinal nerves and may be collected into the sympathetic ganglia of selachian type. After this phylogenetic stage ganglionic commissural fibers may develop.

Some of the visceral fibers are found to pass through the dorsal roots, whose origins have been traced to the cells in the spinal cord, probably to the so-called dorsal cells (JoHnels, 1956). These fibers might be visceral afferents or cholinergic or other non-cholinergic fibers, as dorsal cells did not fluoresce. It may be worthwhile to add that some electrophysiological data suggest that these cells are sensory in nature (RovAINEN, 1967).

\section{Summary}

The spinal cord and intestine of the lamprey (Lampetra japonica) were examined with regard to the occurrence f monoaminergic nerve elements by using the FalckHillarp method.

1. In the spinal cord fluorescent neurons were found near the central canal along the whole length of the cord. Their axons seemed to run chiefly to the ventral side.

2. A pair of fluorescent areas showing fluorescent spots which presumably corresponded to the cut surfaces of the axons or endings of the fluorescent neurons were seen near the ventral surface of the cord.

3. The axons of the fluorescent neurons were supposed to form the fluorescent areas.

4. Neural elements in the wall of the intestine, in the blood vessels to the intestine of the caudal part and in the cloacal sympathetic ganglion (a tentative name for the ganglion present dorsally to the ureter and intestine of the cloacal region) were, as in the case of the intramedullary fluorescent neurons, assumed to be monoaminergic by referring to the simple specificity test for monoamine fluorescence.

5. It is unknown whether the fluorescent neurons in the spinal cord are the source of the fluorescent fibers in the spinal nerves, both in dorsal and ventral roots.

6. The significance of the fluorescent neural elements found in this examination were discussed with reference to the ontogeny and phylogeny of the commissural sympathetic chain and the enteric plexus. 


\title{
カワャツメ脊粗および腸管壁内のモノアミン含有神経細胞について
}

\author{
(内容自抄)
}

カワヤッメの脊髄と腸管壁でのモノアミン含有神経細胞の存否を FALCK-HILLARP に よる螢光組織化学的方法で検索した.

1. 脊髄内中心管の附近に螢光性神経細胞が 会髄のほぼ全長にわたって存在し, こ れら神経細胞の神経線維のほとんどが腹側に向からのが見られた。

2. 脊髄のほぼ腹側面に一対の螢光を発する地域がみられ，これらほ凃䯣内螢光性神 経細胞の神経線維の断面と思われる䖝光性小斑点より構成されているように見えた.

3. 春髄内螢光性神経細胞の神経線維は, 主にこの螢光域に終るものと想像された.

4. これら脊髄内螢光性神経細胞は，腸管へ進入する血管の壁，腸管壁，総排泄口部 交感神経節（総排泄口附近の尿管背側部にある神経節の仮称）にみられた螢光性神経要 素と同様, フォルムアルデヒド処理および非処理標本の比較，レセルピン投与，水酸化 ホウ素ナトリウム試験などの結果から，モノアミン作働性であろうと想像した.

5. 少数ながら脊髄前根および後根にも見られた螢光性神経線維あるいは内臓遠心性 神経線維が，彸髄内螢光性神経細胞に由来するかどうかは，本研究では明らかにできな かった。

6. 交感神経幹や腸壁神経叢の個体発生と系統発生について, 本研究でみられた螢光 性神経要素と関連させて, 若干 論議してみた。

\section{References}

Ayers, H.: Ventral spinal nerves in Amphioxus. J. comp. Neurol. 33: 155-162 (1921). : Amphioxine nerve in Myxinoids. J. comp. Neurol. 50: 464-478 (1930).

Campenhout, E. van: Contribution to the problem of the development of the sympathetic nervous system. J. exp. Zool. 56: 295-320 (1930).

Carlson, A., B. Falck, K. Fuxe and N.-A. Hillarp: Cellular localization of monoamines in the spinal cord. Acta physiol. scand. 60: 112-119 (1964).

Corrodi, H., N.-A. Hillarp and G. Jonsson: Fluorescence method for the histochemical demonstration of monoamines. 3. Sodium borohydride reduction of the fluorescent compounds as a specificity test. J. Histochem. Cytochem. 12: 582-586 (1964).

Dahlström, $\mathbf{A}$ and $\mathbf{K}$. Fuxe: Evidence for the existence of monoamine-containing neurons in the central nervous system. 1. Demonstration of monoamines in the cell bodies of brain stem neurons. Acta physiol. scand 62, Suppl. 232: 1-55 (1965 a).

-: Evidence for the existence of monoamine-containing neurons in the central nervous system. II. Experimentally induced changes in the intraneuronal amine levels of bulbospinal neuron systems. Acta physiol. scand. 64, Suppl. 247: 7-36 (1965 b).

-: Evidence for the existence of an outflow of noradrenaline nerve fibers in the ventral roots of the rat spinal cord. Experientia 21: 409-410 (1965c).

Euler, U.S.V. and E. Östlund: Effects of certain biologically occurring substances on the isolated intestine of fish. Acta physiol. scand. 38: 364-372 (1957).

Falck, B. and Ch. Owman: A detailed methodological description of the fluorescence method for the cellular demonstration of biogenic monoamines. Acta Univ Lund., Sec. II, No. 7: 1-23 (1965). 
Fänge, R.: Effect of drugs on the intestine of a vertebrate without a sympathetic nervous system (Myxine glutinosa). Ark. Zool., 40 A, No. 11: 1-9 (1948).

Fänge, $\mathbf{R}$. and A. Johnels: An autonomic nerve plexus control of the gall bladder in Myxine. Acta zool., Stockh., 39: 1-8 (1959).

Goodrich, E. S.: Studies on the structure and development of vertebrates. London, Macmillan. 1930 .

Hollands, B .C. S. and S. Vanov: Localization of catecholamines in visceral organs and ganglia of the rat, guinea-pig and rabbit. Brit. J. Pharmacol. 25: 307-316 (1965).

Honma, S.: Fluorescence microscopic observations on the brain of the lamprey, Lampetra japonica. Arch. histol. jap. 31: 167-178 (1969).

: Histochemical demonstration of catecholamines in the toad sympathetic ganglia. Jap. J. Physiol. 20: 186-197 (1970 a).

-: Morphology and physiology of the nervous system of the lamprey, Lampetra japonica.

I. The presence of fluorescent neurons in the spinal cord. J. Physiol. Soc. Jap. 32: 373-374 (1970b).

Johnels, A. G.: On the peripheral autonomic nervous system of the trunk region of Lampetra planeri. Acta zool., Stockh., 37: 251-286 (1956).

Kappers, C. U. Ariëns, G. C. Huber and E. C. Crosby: The comparative anatomy of the nervous system of vertebrates, including man. New York, Macmillan, 1936.

Konishi, M.: Fluorescence microscopy of the spinal cord of the dog, with special reference to the autonomic lateral horn cells. Arch. histol. jap. 30: 33-44 (1968)

Kuntz, A.: The development of the sympathetic nervous system in certain fishes. J. comp. Neurol. 21: 177-214 (1911 a).

-1: The sympathetic nervous system in the Amphibia. J. comp. Neurol 21: 397-416 (1911b).

Müller, R.: Beiträge zur Kenntnis des autonomen Nervensystems. I. Ueber die Entwicklung des Sympathicus und des Vagus bei den Selachiern. Arch. mikr. Anat. 94: 208-247 (1920).

Nicol, J. A.: Autonomic nervous system in lower chordates. Biol. Rev. 27: 1-49 (1952).

Norberg, K. -A.: Adrenergic innervation of the intestinal wall by fluorescence microscopy. Int. J. Neuropharmacol. 3: 379-382 (1964).

Rovainen, C.: Physiological and anatomical studies on large neurons of central nervous system of the sea lamprey (Petromyzon marinus). II. Dorsal cells and giant interneurons. J. Neurophysiol. 30: 1024-1042 (1967)

Schultz, R., E. C. Berkowitz and D. C. Pearse: The electron microscopy of the lamprey spinal cord. J. Morphohol. 98: 251-273 (1956).

Yntema, C. L. and W. S. Hammond: The development of the autonomic nervous system. Biol Rev. 22: 344-359 (1947).

Young, J. Z.: The autonomic nervous system of Selachians. Quart. J Microsc. Sci. 75: 571-624 (1933).

本間信治 T951 新潟市旭町 1

新潟大学医学部

第 1 生理学教室
Dr. Shinji Honma

Department of Physiology

Niigata University School of Medicine

951 Niigata, Japan 